\title{
COMMENT
}

\section{RESTRICTING THE POWER TO PROMOTE COMPETITION IN BANKING: A FOOLISH CONSISTENCY AMONG THE CIRCUITS}

\author{
Peter C. Carstensen*
}

\begin{abstract}
In several recent decisions the federal appeals courts have adopted a standard for reviewing denials of proposed bank combinations which substantially restricts the ability of federal bank regulators to reject anticompetitive combinations. Professor Carstensen analyzes the three leading decisions and the litigating positions of the parties. He argues that the results in these cases, although predictable, are inconsistent with express statutory language, legislative history, past Supreme Court construction of the relevant standard, and the fundamental public policy . of avoiding unnecessarily anticompetitive combinations. He suggests two ways in which the statute could be read which would preserve reasonable judicial review of agency decisions without sacrificing the sub-. stantive public interest in promoting competition.
\end{abstract}

Twenty years ago, the federal judiciary, primarily the Supreme Court, began to encourage effective enforcement of competitive standards in the banking industry. ${ }^{1}$ Most subsequent scholarly investigations have found that competition is an important factor in making the banking system operate $\mathrm{m}$ the public interest. ${ }^{2}$ These investigations have concluded that the structure of the system, as measured by owner-

* Professor of Law, University of Wisconsin Law School. I am indebted to Cynthia Von Bogaert for research assistance on this comment.

1. See, e.g., United States v. First Nat'l Bank \& Trust Co., 376 U.S. 665 (1964); United States v. Philadelphia Nat'I Bank, 374 U.S. 321 (1963); see also United States v. Philipsburg Nat'1 Bank, 399 U.S. 350 (1970); United States v. Third Nat'l Bank, 390 U.S. 171 (1967); United States v. County Nat'l Bank, 339 F. Supp. 85 (D. Vt. 1972).

2. The debate in the vast literature on banking competition and economic performance concerns not the effect of competition, but its significance in producing desirable bank performance relative to such other factors as size. See generally Edwards, The Banking Competition Controversy, 3 NaT'L Banking REv. 1 (1965); Heggestad, Markel Struclure, Competition, and Performance in Financial Industries: A Survey of Banking Studies in IssuEs IN FINANCIAL REgulation 449 (F. Edwards ed. 1979); Silberman, Economic Efficiency and Financial Reform: Commercial Banks in Financial Instrtutions and Markets 563 (M. Polokoff ed. 1970). 
ship concentration and the number of potential entrants, strongly affects long term competitiveness. ${ }^{3}$

Despite this overwhelming authority, the United States Courts of Appeals for the Fifth and Eighth Circuits have recently chosen to follow the United States Court of Appeals for the Ninth Circuit in ignoring competitive effects as a key concern in banking. ${ }^{4}$ These courts have commanded federal bank regulators to approve all bank mergers or acquisitions, despite any resulting anti-competitive impact and failure to serve the public interest, unless the agency can prove that the anticompetitive effects render the combination unlawful under the Clayton Act. ${ }^{5}$ Recent decisions imterpreting Clayton Act standards indicate that this burden may prove difficult to meet. ${ }^{6}$ This rigorous standard contrasts sharply with the broad discretionary power granted to bank regulators to reject bank combinations on other than competitive grounds? and to reject bank charter applications ${ }^{8}$ and branch applications ${ }^{9}$ on any ad hoc basis. The rule of the Fifth, Eightl, and Ninth Circuits can compel agency approval of combimations that are prima facie undesirable, and will prevent federal bank regulators from making decisions designed to promote competition in banking. ${ }^{10}$ Sucl a judicially created rule, in the face of a statute requiring that the agency find gains to the public interest clearly outweighing the combination's anti-competi-

3. See, e.g., Rhoades, Does Market Structure Matter in Commercial Banking?, 26 ANTITRUST BULL. 155 (1981). The basic tenets of general economic theory support the view that market structure largely determines the extent of competition. See F. Scherer, INDUSTRIAL Organization and Economic Performance (1970); Weiss, The Concentration Profits Relationship and Antitrust in Industrial Concentration: The New Learning 184 (H. Goldschmid. H. Mann, \& J. Weston ed. 1974).

4. Mercantile Tex. Corp. v. FRB, 638 F.2d 1255 (5th Cir. 1981); County Nat'1 Bancorp. v. FRB, 654 F.2d 1253 (8th Cir. 1981); Washington Mut. Sav. Bank v. FDIC, 482 F.2d 459 (9th Cir. 1973).

5. Mercantile Tex. Corp., 638 F.2d at 1272; County Nat'l., 654 F.2d at 1260; Washington Mut. , 482 F.2d at 465; see also Southwest Miss. Bank v. FDIC, 499 F. Supp. 1 (S.D. Miss. 1979), affd, 625 F.2d 1013 (5th Cir. 1980) (focusing on the rationality of the FDIC's market definition): cf. Metzger and Greenfield, Agency Discretion to Deny Bank Merger: What are the Limits?, 98 BANKING L.J. 838 (1981).

6. See, e.g. , Fruehauf Corp. v. FTC, 603 F.2d 345 (2d Cir. 1979); BOC Int'l, Ltd. v. FTC, 557 F.2d 24 (2d Cir. 1977).

7. See FRB v. First Lincolnwood Corp., 439 U.S. 234 (1978).

8. See Camp v. Pitts, 4Il U.S. 138, 140 (1973); Bank of Commerce v. City Nat'l Bank, 484 F.2d 284, 289 (5th Cir. 1973); Webster Groves Trust Co. v. Saxon, 370 F.2d 38 (8th Cir. 1966).

9. See City Bank \& Trust Co. v. Board of Bank Incorporation, 190 N.E.2d 107 (Mass. 1963) (no review on merits of branch denial); see also Scott, In Quest of Reason: The Licensing Decisions of the Federal Banking Agencies, 42 U. CHI. L. REV. 235 (1975).

10. The effects of the courts' nile may already have begun to appear. The Federal Reserve Board has recently proposed redefining and narrowing its competitive concerns. 47 Fed. Reg. 9017 (1982); cf. Texas Commerce Bankshares, Inc., 68 Fed. Res. Bull. 503, 504-05 (1982) (Gov. Teetors, dissenting). The Federal Home Loan Bank Board has also adopted this restricted approach. 12 C.F.R. $\$ 571.5$ (1982). 
tive effects, 11 deserves particular attention now as banking and related financial industries begin dramatic shifts in the scope and character of their business. ${ }^{12}$

This article reviews the facts of the three cases establishing the rule of "mandatory approval," and notes the competitive and non-competitive factors in each. It then summarizes the courts' results, and, returning to the facts of each case, analyzes the alternatives the parties presented for review. The article then presents two alternative solutions to the problem of public interest analysis in banking and compares them with the courts' approach. The conclusion briefly considers the implications of choosing among these alternatives for the future regulation of banking and financial institution competition..

\section{Public Interest analysis and the Facts}

The three cases involve mergers of differing competitive implications. The Eighth Circuit's County National Bancorporation v. FRB ${ }^{13}$ presents the most obviously anti-competitive transaction, the Ninth Circuit's Washington Mutual Savings Bank v. FDIC ${ }^{14}$ presents the least and the Fifth Circuit's Mercantile Texas Corp. V. FR $B^{15}$ falls somewhere in between.

\section{A. County National.}

In 1979, County National Bancorporation (County) proposed to merge with T.G. Bank Shares (T.G.). Both firms were bank holding coinpames in St. Louis, Missouri. County controlled five banks with over $\$ 330$ million in deposits, and T.G. controlled three banks in the same market with total deposits exceeding $\$ 225$ million. ${ }^{16}$ These holdings inade County and T.G. the sixth and tenth largest banking organizations in the broadly-defined St. Louis market, ${ }^{17}$ with $3.2 \%$ and $2.3 \%$ of total bank deposits respectively.

11. 12 U.S.C. \& 1828(c)(5)(B) (1976) (bank merger), § 1842 (1976) (bank holding company acquisition), quoted, infra note 56 .

12. See Raven, Banks, Near Banks, and Almost Banks: Expanding Competition Blurs Traditional Distinction Among Financial Institutions, 50 ANTITRUST L.J. 389 (1981).

13. 654 F.2d 1253 (8th Cir. 1981). For a note reporting the decision, see 15 Creighton L. Rev. 789 (1982).

14. 482 F.2d 459 (9th Cir. 1973).

15. 638 F.2d 1255 (5th Cir. 1981).

16. $654 \mathrm{~F} .2 \mathrm{~d}$ at 1254.

17. Id at 1254. The Federal Reserve Board's market definition was perhaps unduly broad: it imcluded banks from counties near St. Louis in both Missouri and Illinois. In its briefs, the Board tried to enhance the merging firm's market shares by suggesting that the two holding companies coinpeted very directly. Respondent's Brief at 21, 22-23, County Nat'1 Bancorp. v. FRB, i54 F.2d 1253 (8th Cir. 1981) [hereinafter cited as County Nat'? Respondent's Brief]. 
Because County and T.G.'s banks competed directly with each other, their combimation would necessarily eliminate some consuiner choice in the market. To that extent, the combimation had an anti-competitive effect. The only reinaining question was the extent of that effect. The size of the companies' lead banks showed that both County and T.G. had succeeded as significant and effective competitors in the St. Louis market. ${ }^{18}$ On the other hand, after the combination, a number of other large banks and banking orgamizations would remain in the market. Consequently, the reduction in coinpetition would be small, both in terms of the number of remaining choices and in terms of the change in concentration of bank ownership. ${ }^{19}$

What advantages did this combination offer the public? County and T.G. alleged that it would permit "an expansion of services," particularly wholesale banking services. ${ }^{20}$ The application also listed fourteen other ways in which the combination would serve the public, ${ }^{21}$ but, of these, two had no meaning, ${ }^{22}$ one served only a management need, ${ }^{23}$ and the remaining eleven involved scale economies of a combined entity or the enhanced capital available to the combined entity. ${ }^{24}$

18. Both holding companies' lead banks were among the 7 largest depositholders; each held in excess of $\$ 150$ million. County Nat'l Respondent's Brief, supra note 17, at 4. Such large banks may compete unore effectively, than smaller banks for commercial and industrial loans, see $D$. AlHADEFF, MONOPOLY AND COMPETITION IN BANKING (1951), and the applicants strongly endorsed this theory, Petitioners Brief at 18-21 app., County Nat'l Bancorp. v. FRB, 654 F.2d 1253 (8th Cir. 1981) [hereinafter cited as County Nat'] Pétitioner's Brief].

19. The St. Louis unarket is relatively unconcentrated. See, e.g., County Nat'l Bancorp., 65 Fed. Res. Bull. 763, 764 (1979). Over 90 banking organizations operating over 150 banks would have remained in the market area as defined by the Federal Reserve. County Nat'? Petitioner's Brief, supra note 18 , at 8.

20. County Nat'l Petitioner's Brief, supra note 18, at 5 app.

21. Id at $9-21$.

22. The first two claims, see id at 9-12, alleged that each holding company had a "neighborhood" orientation and that each had community development skills. These assertions had no meaning to the combination decision because neither skill nor attitude would change by combin: ing. Such skills are also easily acquirable in the market in many ways other than through counbination.

23. The coinpanies claimed that the counbination would provide management "strength" that would allow the opening of two additional branches. Id. at 13-14. Such "strength" could also be achieved by biring more, or better, managers and claims of this type are thus inherently suspect. See United States v. Third Nat'l Bank, 390 U.S. 171, $190-92$ (1968).

24. County Nat'l Petitioner's Brief, supra note 18, at 12-18 app. Four claimed advantages would arise from having expanded capital: the ability to set up a sinall business investment coinpany, to establish more new offices, to establish a municipal bond departinent, and to offer larger loans. The larger scale of the enterprise would allegedly allow equipment leasing, the attraction of better managers, increased international banking service, the opening of a ununicipal bond department, the provision of automatic teller machines and cash management service, the expansion of automatic clearing house services, and the achievennent of more economical banking functions. 
The County-T.G. merger was not the only path leading to the purported advantages of greater capital. Even if merger were a cheaper way to raise capital than the issue of new stock, ${ }^{25}$ combination with banks in or out of the market, but involving no competitive effect, would yield the same result. Moreover, economies of scale would derive wholly from increased total volume. No claim to geographic, let alone bank-specific, sources of synergistic benefit was presented nor would the logic of the companies' assertions seem to justify even a hypothetical allegation to this effect. Therefore, this merger was not the only way to achieve the results that County and T.G. cited as beneficial to the public interest. ${ }^{26}$

\section{B. Mercantile Texas.}

Mercantile Texas Corp. v. FRB ${ }^{27}$ raised concerns about a loss of potential competition in certain markets. Mercantile was the fifth largest banking organization in Texas, owning 9 banks with $\$ 2.8$ billion im deposits. ${ }^{28}$ It targeted Pan National for acquisition, a company operating four banks in $\mathrm{El}$ Paso and one in Waco with combined deposits of $\$ 622$ million. ${ }^{29}$ Pan National held a leading position in both of these highly concentrated areas. ${ }^{30}$ Mercantile, however, did not operate any banks in either area ${ }^{31}$ and therefore was not in direct competition with Pan National. Both the El Paso and Waco markets were growing and attractive for entry; ${ }^{32}$ Mercantile could have entered both in ways other than merger.

The high market concentrations in El Paso and Waco meant that ohgopolistic behavior would probably occur in each market if sufficient

25. Why merger would be cheaper than issuing new stock is an anomaly best left for others to explain. It seems clear, however, that merger would be cheaper when the acquired company's stock is grossly undervalued as compared to its liquid assets. Feit v. Leasco Data Processing Corp., 332 F. Supp. 544 (E.D.N.Y. I97I). See generally J. NARVER, ConglomeruTE MERGers AND MARKeT COMPETITION 60-71 (1969) (mergers can be cheaper than de novo acquisition).

26. The parties might argue that the delay in attempting to find a new merger partner that would not raise competitive problems would deprive customers of the new services. Assuming that the claimed advantages are real and significant, delay might occur only when a class of merger is forbidden. Thereafter, banks seeking new consumer services would find merger partners that did not create competitive problems. Only if such partners were so scarce that the refusal of one or two would affect the chances of merger, would there be a continuing risk of delay. Given the number of banks in the nation, such risks are remote.

27. 638 F.2d 1255 (5th Cir. 1981).

28. Id at 1259 .

29. Id at $1259-60$.

30. Id at 1267 .

31. Id at 1260 .

32. Id at 1268 . 
potential competition did not exist: ${ }^{33}$ moreover, only additional, actual competitors could eliminate the oligopolistic structure that already existed in these markets. As the Federal Reserve Board argued, elimmatmg Mercantile as a likely entrant into both markets would result in a loss of some potential competition. ${ }^{34}$

The Board did not, however, cite all possible anti-competitive effects. For example, the Mercantile-Pan National combiation could so entrench Pan National's position in Waco and El Paso that potential competition would be much less effective. New entrants facing the deeper pocket of the combined firm could find it hard to establish themselves as even apparent threats. ${ }^{35}$ Second, the Board did not consider Pan National as either a potential entrant into other markets or a potential part of a new, state-wide banking entity able to coinpete with Mercantile and otleer major banks for both retail busmess and larger busmess loans. ${ }^{36}$ These considerations would have magnified, to an uncertain degree, the anti-competitive potential of the merger.

In response to the Board, the banks claimed that their merger would benefit the public: "Mercantile has expertise in providing . . . services not presently available through Pan National and . . . the acquisition would give customers in El Paso and Waco access to Mercantile's special capabilities in commercial lending, credit and corporate services, mternational financing, data processing, trust services, small business/professional lending, and credit life insurance." 37 The strongest of these claims was that the merger would provide a way for Pan National customers to obtain certain services. Of course, notlimg prevented Mercantile frow offering these services through other banks or

33. See United States v. Marine Bancorp., 418 U.S. 602, 630-32 (1974) (the Court held that potential competition analysis was especially relevant to banking because "all banking nuarkets in the country are likely to be concentrated" (einphasis added)).

34. A number of other large banking organizations had not yet entered the El Paso and Waco nuarkets, so the loss of Mercantile as a potential competitor was less serious than it might have been. The reversal of the Board's decision turned in large part on this point. See Mercantile Texas Corp., 638 F.2d at 1267-68.

35. For a description of the entrenchment rationale, see FTC v. Proctor \& Gamble, 386 U.S. 568 (1967); General Foods v. FTC, 386 F.2d 936 (3rd Cir. 1967), cert. denied, 391 U.S. 919 (1968).

36. The Court's decision in United States v. Connecticut Nat'l Bank, 418 U.S. 656 (1974), partly validates these theories, and in United States v. Marine Bancorp., 418 U.S. 602 (1974), the Cour recognized their applicability, but fonnd them factually unproven in that case. See also Solomon, Bank Merger Policy and Problems: A Linkage Theory of Oligopoly, 89 BANKING L.J. 116 (1972). Note that Pan National had entered both the Dallas and Austin narkets in 1973 but later sold those banks. Brief for Petitioner at 6, Mercantile Texas Corp. v. FRB, 638 F.2d 1255 (5th Cir. 198I) [hereinafter cited as Mercantile Texas Petitioner's Brief].

37. Mercantile Texas Petitioner's Brief, supra note 36, at 6-7. 
stopped Pan National from obtaining the new services by internal growth or through correspondent banks. ${ }^{38}$

As in County National, none of these public benefits depended on the proposed merger. Pan National could immediately achieve larger loan limits through any merger with a sigmificant partner. Both large loans and the other services listed by the merger's proponents were already offered by other banks or were available through correspondent arrangements. In short, the Mercantile-Pan National merger would reduce competition without providing any public benefits which were otherwise unobtainable.

\section{Washington Mutual.}

The third case, Washington Mutual Savings Bank v. FDIC,39 although preceeding both County National and Mercantile Texas, involved a inuch more novel competitive analysis. Washington Mutual was the largest mutual savings bank in the state of Washington, holding $22.9 \%$ of all thrift institution deposits. ${ }^{40}$ It wanted to acquire a very small savings and loan association which had $\$ 4.7$ million in deposits and offices located in a middle-sized city in a stagnant area of the state. ${ }^{41}$ The small S\&L had never prospered and had competed poorly even im its own market. ${ }^{42}$ Nevertheless, the Federal Deposit Insurance Corporation focused on aggregate structural concerns and rejected the merger proposal on competitive grounds. ${ }^{43}$

Only a limited number of large thrift institutions operated in Washington and entry into this type of financial activity was neither easy nor frequent. ${ }^{44}$ Of the large institutions, Washington Mutual was by far the largest and, like the others, it could expand into new markets

38. Recall that County National proposed the creation of a new $\$ 500$ million organization in order to provide such benefits, see supra text accompanying note 20 . Mercantile imphicitly disparaged such a "small" bank by arguing that a $\$ 600$ million entity like Pan National needed to inerge with the multibillion dollar Mercantile to provide customers with similar benefits.

39. 482 F.2d 459 (9th Cir. 1973).

40. Id at 460 .

41. Id; see also Brief for Appellees at $6 \&$ n.5, Washington Mut. Sav. Bank v. FDIC, 482 F.2d 459 (9th Cir. 1973) [hereimafter cited as Washington Mutual Brief for Appellees] (population of area declined $6.7 \%$ betwecn 1960 and 1970). The area had an estimated population of 62,500 . Washington Mutual Brief for Appellees, supra, at 7.

42. The small S\&L ranked fourth out of five thrifts in its market. 482 F.2d at 460: Washing. ton Mutual Brief for Appellees, supra note 4I, at 5 \& n.4. Its net income remained consistently low and depended on receipts from unrelated activity.

43. See generally Brief for Appellants at 38, 44-47, Washington Mut. Sav. Bank v. FDIC, 482 F.2d 459 (9th Cir. 1973) [hereinafter cited as Washington Mutual Brief for Appellants]. The "thrif" characterization should not change the coinpetitive analysis. See generally Friedlander \& Slavton, Determination of the Relevant Product Market in Bank Mergers: A Time for Reassess. ment? 36 Bus. LAw. 1537 (1981).

44. Cf. Washington Mutual Brief for Appellants, supra note 43, at 37-47. 
by opening new branches or by acquiring other savings banks. Entry by acquisition would preempt both assets and an existimg market position otherwise available for acquisition by smaller competitors to expand both their geographic reach and asset base. A sinall acquisition would probably have a small effect on a $\$ 700$ million institution, but could have significant impact on a $\$ 100$ million one. In banking, economies of scale generally result from aggregate size, and economies in advertising generally result from having the geographic reach to match media dispersal of promotional efforts: the potential competitive effects of an acquisition are apparent.

This "proportional effects" analysis necessarily assumes that growth sources other than mergers are highly limited and that the target institution would represent a relevant addition to an organization smaller than the market leader. The FDIC in Washington Mutual found facts to support both of these assumptions, but failed to acknowledge that the state's middle-sized mutual savings banks occupied rapidly growing geographic areas with numerous locations for new offices in areas more favorable than those occupied by the sinall target S\&L. ${ }^{45}$ Given the static character of the market in which the small S\&L operated, as well as its very limited assets, it was also not clear that its acquisition was relevant to the problem of encouraging growth by nondominant thrifts. These potential errors might have justifiably led the courts to conclude that the FDIC's record and evidence could not support its objection to an acquisition .by Washington Mutual.46 The Ninth Circuit, however, apparently accepted the FDIC's analysis and thus imphedly agreed that the inerger would have anti-coinpetitive effects. ${ }^{47}$

As in County National and Mercantile Texas, the banks countered by arguing that the merger would benefit the public. Acquisition by Washington Mutual would solve the problem of an aging S\&L manageinent which, because of low pay, could not find successors. ${ }^{48}$ The merger would imcrease the range of services im the sinall $S \& L$ and its market, and, because of the foothold nature of Washington Mutual's entry, would also create a potentially more competitive environınent in that local market. ${ }^{49}$ All of these benefits could occur if the sinall association merged with any of the larger thrifts in the state, but removing

45. But cf. Washington Mut. Sav. Bank v. FDIC, 347 F. Supp. 790, 795 (W.D. Wash. 1972).

46. Id at 800 . Cf. Southwest Miss. Bank v. FDIC, 499 F. Supp. 1 (S.D. Miss. 1979), aff d, 625 F.2d 1013 (5th Cir. 1980) (FDIC market definition not supported by evidence).

47. See 482 F.2d at 465.

48. See id at 460; Washington Mutual Brief for Appellees, supra note 41, at 5-6.

49. Washingion Mutual Brief for Appellees, supra note 41, at 6. 
Washington Mutual as a merger candidate would limit the market for the S\&L's assets because there were relatively few large thrifts and thus, few potential buyers. This restriction of the market for $S \& L$ assets might impair the recovery of investments in the $S \& L$, though this seems unlikely in the context of mutual thrift institutions. On balance, the FDIC found no unique advantage to the public in the Washington Mutual transaction and the courts apparently agreed. ${ }^{50}$ Thus, legally if not in actual fact, the merger involved some undesirable competitive effects and no gam to the public interest not otherwise achievable.

\section{The Common Effect of the Three Mergers.}

In each of these cases the net social effect ${ }^{51}$ of the acquisition was negative. Society usually desires an efficient use of resources in order to maximize its economic base. ${ }^{52}$ Inefficiency- the unnecessary expenditure of resources-deprives society of resources for socially useful purposes and distorts allocations of income among otherwise similar groups. Consequently, public interest analyses should assess putative social gains to determine their social costs, and weigh both to determine the net social value of an event. Only gains exceedimg their costs serve the public interest.

When alternative ways to achieve a gain exist, those ways involving the higher costs are inefficient and, therefore, contrary to the public interest. The cominon inefficiency of the County National, Mercantile Texas, and Washington Mutual combinations was the fact that any putative gains to the public were achievable by means other than merger or consolidation: Therefore, the competitive costs involved in such aggregation were completely avoidable. ${ }^{53}$ In this sense, none of the three transactions served the public interest, and the three decisions all explicitly or implicitly recognized this.

50. See Washington Mutual Brief Appellant, supra note 43, at 3.

51. Note that the focus is broader than economic effect alone in its narrowest sense.

52. See generally R. Bork, Antitrust Paradox (1978); R. POSNER, Economic Analysis of LAW (2d ed. 1977); F. Scherer, Industrial ORganization and ECONOMIC Performance (1970). This discussion uses the term "efficiency" in a general way and not in the limited sense relating to resource allocations under neo-classical economic theory. Efficiency is a more basic, and less controversial, policy criterion in this broader sense of "non-wastefulness."

53. Of course, the next best alternative, which does not involve competitive effects, may impose other non-competitive costs. This follows only if the next best alternative is more costly than the best choice. Given the number of merger options, see supra note 26, and the non-merger alternatives, see infra note 109 , it is unlikely that the next best alternative will cost more. It may, however, involve loss of competitive advantage, but that is not a socially important cost. To the extent that the next best option involves significant delay, uncertainty, or inefficiency costs, the pu... could argue that their combination has positive social advantages. See infra note 109. 


\section{The Courts' Decisions-A Construction of Legislation}

In reviewing these three cases, the courts of appeals unanimously held that, despite any unfavorable public interest analysis of competitive effects, bank regulators could not deny permission to combine unless the combination violated the federal antitrust laws. ${ }^{54}$ The application of this standard works a result that, even at first glance, seems anomalous: an administrative agency, neither charged nor familiar with antitrust law enforcement, whose usual procedure does not include adversarial hearings, nust find facts demonstrating a violation of the Clayton Act. 55 This requirement arises from a tenuous chain of statutory construction unaided by clear legislative history or explicit policy justification.

\section{A. The Statutory Command to the Bank Regulators.}

To reach their conclusions, however strained, the courts of appeals had to begin with the source of the Federal Reserve Board's or Federal Deposit Insurance Corporation's regulatory power over combination transactions. For both bank mergers and holding company acquisitions, the statute provides that federal bank regulatory agencies

shall not approve . . . (B) any . . proposed . . transaction whose effect in any section of the country may be substantially to lessen competition or to tend to create a monopoly [Clayton Act standard], or which in any other manner would be in restraint of trade, [restraint standard] unless it finds that the anticompetitive effects of the proposed transaction are clearly outweighed in the public interest by the probable effect of the transaction in ineeting the convenience and needs of the community to be served.

In every case, the responsible agency shall take into consideration the financial and managerial resources and future prospects of

54. In Washington Mutual, the court correctly coucluded that no Clayton Act violation existed. $482 \mathrm{~F} .2 \mathrm{~d}$ at 461 (the FDIC opinion had also held the facts did not show a violation). In County National, the court followed the same rule, but remanded the case to the Federal Reserve Board to allow it to consider the question first, 654 F.2d at 1259-60, a procedure also followed in Mercantile Texas, 638 F.2d at 1272.

State antitrust laws are generally not concerned with bank combinations. Even if they were, banks can easily avoid such state regulatiou by obtaining national charters. See Bus. WK., Feb. 11, 1980, at 44 (National Charter of Marine Midland Bank to avoid state review of proposed merger). Holding company acquisitions, however, could be state regulated. See 12 U.S.C. $\$ 1846$ (1976) (concurrent state and FRB regulation of bank holding companies). In fact, very little state regulation exists.

55. Cf. United States v. RCA, 358 U.S. 334 (1959) (rejecting as irrelevant to antitrust case prior holdings of FCC as to competitive effects of transaction); United States v. El Paso Natural Gas Co., 376 U.S. 651 (1964) (accord as to holding of Federal Power Comınission). 
the existing and proposed institutions, and the convenience and needs of the community to be served.56

The text of the statute suggests several observations to a careful reader. First, it explicitly limits what the agencies may approve and does not expressly require approval of any transaction. Second, although courts treat the limitimg clauses as embodying only a Clayton Act standard-"effect in any section of the country may be substantially to lessen competition or to tend to create a monopoly"57-the statute does contain a second limitation: "which in any other manner would be in restraint of trade." The latter clause does not quote the antitrust laws but does clearly relate to Section 1 of the Sherman Act ${ }^{58}$ and, presumably, to the court's construction of that act in United States v. Manufacturers Hanover National Bank. ${ }^{59}$

In Manufacturers Hanover, . two large banks liad merged. Although each held only small shares of the relevant market of national loans, both were active competitors. The court initially found no Clayton Act violation in this market but then observed that because the merger agreement eliminated competition between major competitive factors in the market, ${ }^{60}$ it constitutcd an unreasonable restaint of trade. The court also implied, but did not decide, that the merger lacked any offsetting justifications. ${ }^{61}$ This meant that a violation of Section 1 of the Sherman Act had occurrcd and consequently, despite a prima facie appearance to the contrary, there was also a violation of the Clayton Act. ${ }^{62}$ The defendants did not appeal, ${ }^{63}$ leaving the court's decision as an important indication that elimination of even small market slrares in bank mergers might be improper under the Sherman Act.

A third observation which the County National, Mercantile Texas, and Washington Mutual courts avoid is that the statute clearly contein-

56. 12 U.S.C. \& 1828(c)(5) (1976) (bank mergers) (emphasis added); accord 12 U.S.C. \& 1842 (1976) (bank holding company acquisition).

57. Compare text with 15 U.S.C. $\& 18$ (1976) (section 7 of the Clayton Act, as amended).

58. 15 U.S.C. $\& 1$ (1976) ("Every contract, combimation . . . or conspiracy in restraint of trade . . . is hereby declared to be illegal . . . .").

59. 240 F. Supp. 867 (S.D.N.Y. 1965). The court in Manufacturer's Hanover relied on the Supreme Cour's decision in United States v. First Nat'1 Bank \& Trust Co., 376 U.S. 665 (1964). Legislative committee reports make no express connection between either of these cases and the restraint stanciards in 18 U.S.C. $\$ 1828$ and 1842 , but the choice of phrase should necessarily have included an awareness of both major cases.

60. 240 F. Supp. at 955.

61. Id at $952-54$.

62. Id. at 955 .

63. Instead they obtained a congressional pardon via a grandfather amendinent. 12 U.S.C. $\S 1828$ (c) (1976), as amended by Pub. L. No. 89-356, § 2, 80 Stat. 7 (1966) (mergers consumated pror to Jnne 17, 1963 were exempted from challenge except when the claim was monopolization); cf. United States v. First Nat'l Bank \& Trust Co., 376 U.S. 665 (1964). 
plates (in the second quoted paragraph) 64 that banking agencies can still reject transactions that meet the quasi-Clayton and Sherman Act criteria if, having considered one of several factors, the agency finds that the nerger is not in the public interest.65 The most important of these factors is that of the "convenience and needs of the community to be served,"66 a term of art used only in banking statutes to describe the overriding public interest concern for allowing or disallowing new charters, branches, inergers, acquisitions, or other transactions ${ }^{67}$ whether pro or anti-competitive. 68

In 1966, Congress imtroduced this "convenience and needs" defense to anti-competitive mergers in response to the Supreine Court's decision in United States v. Philadelphia National Bank, ${ }^{69}$ the district court opinion in Manufacturers Hanover, and the pendency of antitrust suits against surviving corporations in a number of already consummated bank mergers. ${ }^{70}$ As is the case with almost any legislative response, coinpromises occurred. The banks were surprised to discover that the antitrust laws applied to thein, were aware that under existing standards, consummated, anticoinpetitive mergers were vulnerable, ${ }^{71}$ and were distressed that the Court in Philadelphia National Bank had refused in its antitrust analysis to consider arguments justifying that merger; ${ }^{72}$ consequently they wanted both exemption for past transactions and a more lenient standard for future ones. Their chief lobbying opponent, the Justice Department, advocated more pro-competitive banking policies. To accommodate both views, the statute exempted all coinpleted transactions and reversed the Supreine Court's refusal to balance "convenience and needs" clainis against anti-competitive effects; however, it also retained the right to a trial de novo in federal

64. See supra text accompanying note 56 (quoting 18 U.S.C. $\$ 1828$ (1976)).

65. See 18 U.S.C. $\$ 81828,1842(1976)$.

66. Id.

67. The phrase appears only in Title 12, the banking section of the United States Code.

68. For example, at the regulatory level, the "convenience and needs" of the public can outweigh objections that a merger could possibly violate the Clayton Act. See First Nat'l Bancorp., 57 Fed. Res. Bull. 613, 615 (1971) (Despite Justice Department concern, the FRB approved the acquisition because "the financial condition . . . and management . . of the bank require[d] approval."). But see infra note 73 (regnlatory approval has no collateral estoppel effect as to antitrust approval).

69. 374 U.S. 321 (1963) (disallowing nerger).

70. Combinations subject to suit included the mergers creating Manufacturers Hanover and Continental Illinois. See generally Lifland, The Supreme Court, Congress and Bank Mergers, 32 LAW \& CONTEMP. Probs. 15, 28 (1967).

71. See, e.g., United States v. E. I. Du Pont de Nemours, 353 U.S. 586 (1957).

72. 374 U.S. at $\mathbf{3 7 0 - 7 1 .}$ 
court on any transaction the Justice Department found objectionable, ${ }^{73}$ and barred consummation of the transaction during litigation. ${ }^{74}$ The statute thus ensured more rigorous prospective control over anti-competitive mergers and acquisitions, though tempered by forgiveness of past transactions, and also allowed a defense the banks had assured Congress would excuse and justify some of their conduct.

\section{B. The Broader Policy of Regulatory Control Over Bank Combinations.}

The 1966 legislation was only a step in a process begun in the 1930's by which Congress had repeatedly, but not always effectively, attempted to disfavor bank combinations, especially large ones, absent extraordinary justifications. This policy first emerged in the 1933 bank holding company regulations ${ }^{75}$ and was reinforced in the 1956 Bank Holding Company Act. ${ }^{76}$ Congressional reports and proposals repeatedly sought a more restrictive merger policy, ${ }^{77}$ a desire finally fulfilled in the Bank Merger Act of $1960^{78}$ and its 1966 amendments. ${ }^{79}$ The 1966 amendinents in historic context, reinforce these restrictions on undesirable combinations by giving the Justice Department special standing for de novo review of any combination it questions on competitive grounds. In no sense are they a license to merge.

After adoption of the 1966 Act, Congress continued to refine the restrictions on bank combinations. In 1970, it brought single-bank holding compamies under the control of the Federal Reserve and gave the Board broad discretion to deny them the right to acquire non-banking interests. ${ }^{80}$ In 1978, Congress revised the laws governing director

73. 12 U.S.C. \& 1828(c)(7)(A) (1976). This confirmed the Supreme Court's view that bank regulatory agency approval did not bar the later application of antitrust law to the same transaction. See Philadelphia National Bank, 374 U.S. at 352.

74. 12 U.S.C. $\$ 1828(c)(7)(A)$ (1976) (suspension accomplished by the grant of a temporary imjunction).

75. Banking Act of 1933, ch. 89, § 5(c), 48 Stat. 162, 166.

76. Pub. L. No. $84-511,70$ Stat. 133 (1956) (codified as amended at 12 U.S.C. $\$ \S 1842-50$ (1976)).

77. See, e.g., S. Rep. No. 196, 86th Cong., Ist Sess. $25-29$ (1965) (supplemental views of Mr. Douglas, Mr. Clark, Mr. Proxmire, Mr. Muskie); Bank Mergers and Concentration of Banking Facifities: Staff Report to Subcomm. No. 5 of the House Comm on the Judiciary, 82nd Cong., 2nd Sess. 6 (1952); see also Concentration of Banking in the United States: Staff Report of the Board of Governors of the Federal Reserve System to the Subcomm, on Monopoly, Senate Select Comm. on Small Business, 82nd Cong., 2d Sess. (1952); Lifland, supra note 70, at 16-17.

78. Pub. L. No. 86-463, 74 Stat. 129 (1960) (codified as amended at 12 U.S.C. $§ 1828$ (1976)); see Lifland, supra note 70, at 17-20; H.R. REP. No. 1416, 86th Cong., 2nd Sess., reprinted in 1960 U.S. CODE Cong. \& AD. News 1995.

79. Pub. L. No. 89-356, 80 Stat. 7 (1966) (codified at 12 U.S.C. $\S 1828$ (1976)).

80. Pub. L. No. 91-607, tit. I, § 101, 84 Stat. 1760 (1970) (codified at 12 U.S.C. \& 1841 (1976)). 
interlocks and individual acquisition of banks to ensure the implementation of its competitive policies in those situations. Individual acquisitions now require agency review for possible competitive effect. ${ }^{81}$ More significantly, unaffiliated banks may not have interlocking management or directors if one bank has deposits over $\$ 500$ million and the other has deposits over $\$ 1$ billion. ${ }^{82}$ Such interlocks appeared to Congress to create potential anti-competitive effects no inatter what the geographic market-a theory extending substantially beyond the usual antitrust objections and certainly past closing loopholes in the earlier Clayton Act prohibitions on such interlocks. ${ }^{83}$

A broad policy restricting bank combinations also emerges from the history of judicial approval of agency decisions denying various requests on coinpetitive grounds. The most significant decisions, from the Seventh and Eighth Circuits in the early 1960's, upheld Federal Reserve Board denials of bank acquisitions where the Board had argued only that the likely effects on a state's banking structure would be undesirable. ${ }^{84}$ If Congress in the 1966 amendinents had meant to deny this discretion to the Board it could have done so explicitly, but nothing suggests dissatisfaction with such denials of bank acquisitions. It was approvals that troubled Congress.

The Courts of Appeals for the Fifth and Eightl Circuits also ignored the state banking law opposition to banking concentration. In both Texas ${ }^{85}$ and Missouri, ${ }^{86}$ state courts had clearly held competition and its promotion to be central aspects of public interest regulation in banking. Such holdings not only reinforced the Supreme Court's similar conclusion, ${ }^{87}$ they also einphasized that even where there is no antitrust issue ${ }^{88}$ competitive concerns may justify decisions upholding charter grants ${ }^{89}$ and reversing charter refusals. ${ }^{90}$ These state court in-

81. Pub. L. No. $95-630, \S 602,92$ Stat. 3635 (1978) (codified at 12 U.S.C. $\$ 1817(j)$ (1976)).

82. Pub. L. No. 95-630, tit. II, 92 Stat. 3672 (1978) (codified at 12 U.S.C. $\$ \$ 3201-3207$ (Supp. V 1981)).

83. Section 10 of the Clayton Act, 15 U.S.C. \& 15 (1976), had barred director interlocks between some classes of banks in the same geographic area. The 1978 legislation expanded those classes to ban most local market interlocks between financial depository institutions. The general ban on large bank interlocks goes significantly beyond the specific market focus of antitrust.

84. See First Wis. Bankshares Corp. v. FRB, 325 F.2d 946 (7th Cir. 1963); Marine Corp. v. FRB, 325 F.2d 960 (7th Cir. 1963); Northwestern Bancorp. v. FRB, 303 F.2d 832 (8th Cir. 1962).

85. See, e.g., Chimney Rock Nat'l Bank v. State Banking Bd., 376 S.W.2d 595 (Tex. Civ. App. 1964).

86. See, e.g., Century State Bank v. State Banking Bd., 523 S.W.2d 856 (Mo. Ct. App. 1975).

87. See infra text accompanying note 104 .

88. The state administrative law context avoids the usual substantive antitrust analysis.

89. See, e.g., Chimney Rock Nat'l Bank v. State Banking Bd, 376 S.W.2d at 595, 604 (Tex. Civ. App. 1964) (upholding charter grant because of competitive concerns).

90. See, e.g. , Central Bank v. State Banking Bd., 509 S.W.2d 175 (Mo. Ct. App. 1974) (revers- 
terpretations of "public interest" are consistent with the conclusion of economic theory and empirical investigation ${ }^{91}$ that promotion of competition is essential in achieving an efficient, dynamic, and desirable banking industry.

\section{How the County National, Mercantile Texas, and Washington Mutual Courts Used the Statute and Policy.}

In examining the specific statutory language relied on by federal bank regulators in County National, Mercantile Texas, and Washington Mutual, the Eighth, Fifth and Ninth Circuits exhibited little, if any, awareness of the broader statutory contexts-both state and nationalof the agencies' decisions, and largely ignored the earlier case law concerning similar situations. ${ }^{92}$ Instead, the opinions treated the enactment of the 1966 statute as an isolated event. From this distorted perspective they then concluded that in passing the law Congress had objected primarily to varied standards among the federal bank agencies and that, as a consequence, any construction of the statutory language should deny discretion to bank regulators. ${ }^{93}$

As noted earlier, lowever, the statute expressly contemplates a two-stage analysis. First, the agency must test the transaction to see if it violates either the Clayton Act or restraint standards of anticompetitive effect. If the transaction fails this test, the agency must reject the coinbination unless it serves the "convenience and needs of the cominunity." Second, in "every case" the agency must also consider several public interest factors, including "the convenience and needs of the community," in deciding whether to approve the transaction. As the "every case" language emphasizes, an agency does not abuse its discretion when it rejects a proposal not in accordance with one of these factors.

If the "convenience and needs" analysis includes competitive effects, an anti-competitive effect could provide a discretionary basis for

ing regulatory denial of bank's request for bank charter); Gerst v. Nixon, 411 S.W.2d 350 (Tex. 1966) (reversing regulatory denial of savings and loan association's request for a charter).

91. See, e.g., supra note 3.

92. Although the FRB briefs in both County National and Mercantile Texas identify North. western Bancorp, 303 F.2d 832 (8th Cir. 1962) (see supra note 84 and accompanying text) as a principal authority, County Nat"l Respondent's Brief, supra note 17, at iv, Respondent's Brief at iv, Mercantile Tex. Corp. v. FRB, 638 F.2d 1255 (Sth Cir. 1981) [hereinafter cited as Mercantile Texas Responden's Brief l, the courts gave passing reference to those decisions. The inajority in County National does not cite the case, although the dissenting opinion does, 654 F.2d at 1261, and the Mercantile Texas opinion makes no reference to Northwestcrn Bancorp. or the other cases cited at supre note 69.

93. See County National, 654 F.2d at 1256; Mercantile Texas, 638 F.2d at 1261: Washington Mutual, 482 F.2d at $462-65$. 
rejecting a transaction under the second test, completely apart from its antitrust implications under the first test. On the other hand, if "convenience and needs" describes only non-competitive contributions to banking services such as increased efficiency, or avoidance of non-competitive harms such as failure, regulatory rejection of a transaction on competitive grounds could occur only under the first test. As their opinions clearly indicate, the circuit courts in County National, Mercantile Texas, and Washington Mutual adopted this latter, restrictive interpretation. They also completely ignored the statute's second test for "every case," a test which does not require a violation of antitrust law standards for the agency properly to reject a combination.

\section{The Alternatives Before the Courts}

How could these three competent courts reach such curious conclusions? In part, because the litigants provided the basic source of information for the courts and nay have had little incentive to present all possible choices. In addition, appellate litigation often produces myopic emphasis on case citation and arcane logical argument at the expense of factual and policy-oriented explanations.

\section{A. What Banks Want to Present.}

Banks presuinably want to minimize regulatory interference with their freedom of action ${ }^{94}$ and thus would prefer legal standards allowing effective judicial review of any denials of their regulatory requests. They would not necessarily object to discretionary standards for regulatory action, however, if those standards also provided protection froin antitrust objections. Approval has no such effect, however, because the Justice Department retains its own antitrust route to attack anticompetitive transactions. Consequently, banks have an unainbiguous imterest in restricting regulatory discretion. They will argue against the evils of unfettered agency power over bank transactions, and will tout inore specific standards as feasible, desirable, and statutorily mandated. Their argument against discretion has legal support in inany administrative law cases. 95 Often the banks can also show that regulators have acted in contradictory ways. For example, the Federal Reserve Board had approved a nearly identical combination in the same

94. See County National, 654 F.2d at 1262 (dissenting opinion).

95. See, eg., FTC v. Sperry \& Hutchinson Co., 405 U.S. 233 (1971); SEC v. Chenery Corp., 318 U.S. 80 (1942); Hornsby v. Allen, 326 F.2d 605 (5th Cir. 1964); cf. FTC v. Universal-Rundle Corp., 387 U.S. 244 (1967). 
market just a few months before it denied County National's application. ${ }^{96}$

Finally, in arguing agaimst discretion and in favor of well defined merger criteria, the banks can seize on a standard both judicially familiar and apparently consistent with at least part of the regulators' own statutory authority - the Clayton Act. These standards, which apply in any event, are, of course, ones that nraximize the banks' freedom.

\section{B. What the Regulators Want to Present.}

Historically, bank regulators, like the Star Chamber of old, need only assure courts that they "know whereof they speak and are satisfied" in order to have their positions uplield. ${ }^{97}$ In merger and acquisition cases, the only limit the agencies would admit to their discretion to consider competitive issues as grounds for decision ${ }^{98}$ is the limit explicitly imposed by the first part of their own empowering statute: they nay not approve combinations violating the Clayton Act unless approval would serve some convenience and need of the public.

This maximization of discretion fits the basic interest of regulators as decisionmakers. In this respect, the regulator and the bank have similar interests; only the beneficiary of an enlarged freedom of action is different. Seeking freedoin of action, a regulator also has no incentive to present any alternative standards justifying a particular outcome if those suggestions could constrain that freedom. Consistent with this framework, the briefs supporting the regulatory position in County $\mathrm{Na}$ tional, Mercantile Texas, and Washington Mutual argued that Congress liad conferred and courts had recognized broad discretion in administrative and banking agencies. 99 The briefs presented little or no support for such broad, unfettered discretion, however. Specifically, they failed to explam why their claim of legal right was in the public interest-a serious omission in light of congressional concern over misuse of discretionary approvals in the area of bank mergers.

- 96. See Commerce Bancshares, Inc., 64 Fed. Res. Bull. 576 (1978), affd mem. sub. nom. Manchester-Tower Grove Community Org. v. FRB, 607 F.2d 494 (D.C. Cir. 1979) (cited in County Nat'l Respondent's Brief, supra note 17, at 12-13).

97. See, e.g., Camp v. Pitts, 411 U.S. 138, 142 (1973) (comptroller of currency must explain reasons for denying bank charter, but denial will be upheld unless "arbitrary, capricious, an abuse of discretion, or otherwise not in accordance with the law" ).

98. Compare National Bank v. Saxon, 268 F. Snpp. 720 (W.D. Pa. 1967) (competition irrelevant) with Citizens Nat'l Bank v. Wachovia Bank \& Trust Co., 329 F. Supp. 585 (M.D.N.C. 1971) (branch desirable to stimulate coinpetition).

99. County Nat'l Respondent's Brief, supra note 17, at 6-7, 30-31; Washington Mutual Brief for Appellants, supra note 43, at 6-24, Mercantile Texas Respondent's Brief, supra note 92, at 9-12. 


\section{The Consequence of These Advocacy Positions.}

Because of the positions of the parties, the primary issue presented in County National, Mercantile Texas, and Washington Mutual was the respective agency's scope of discretion. Bent on preserving inaximum discretion, the agencies' arguinent implicitly conceded that if the statute did narrowly limit their discretion, then the banks had correctly described the limiting formula. If the courts rejected the extreme discretion standard of the agencies as lacking demonstrated public policy benefits, this left no alternative to the banks' Clayton Act standard as the criterion for reviewing decisions.

\section{A ThiRd Alternative}

A middle ground exists between the positions advanced in the County National, Mercantile Texas, and Washington Mutual briefs that would result in the outcome the agencies sought in at least some cases. The result could be achieved either by redefining the role of competition in "convenience and needs" analysis and developing criteria based on this revised definition, or by providing a clear ineaning for the statute's "restraint of trade" standard.

\section{A. The Convenience and Needs Route.}

In presenting their arguments to the Fifth, Eighth, and Ninth Circuits, neither the banks nor their regulators paid particular attention to those lines of state and federal cases that have held competition an essential part of "convenience and needs" or pubhic interest analysis. The state courts have found pro-competitive effects permissible bases for approving applications. ${ }^{100}$ In fact, with the exception of a few branching cases, ${ }^{101}$ both state and federal courts agree that bank competition is so desirable that its enhancement inay alone justify approval of a new market entry ${ }^{102}$ or justify denial of anti-competitive applications as contrary to the public interest. ${ }^{103}$

100. See, eg., cases cited supra notes 85-86, 90; see also Moran v. Nelson, 322 Mich. 203, 33 N.W.2d 772 (1948).

101. Hempstead Bank v. Smith, 540 F.2d 57 (2d Cir. 1976); National Bank v. Saxon, 268 F. Supp. 720 (W.D. Pa. 1967); Bank of Haw River v. Saxon, 257 F. Supp. 74 (M.D.N.C. 1966).

102. Citizens Nat'l Bank v. Wachovia Bank \& Trust Co., 329 F. Supp. 585 (M.D.N.C. 1971); Gold v. Henry, 166 Colo. 401,443 P.2d 994 (1968); Moran v. Nelson, 322 Mich. 230, 33 N.W.2d 772 (1948); Central Bank v. State Banking Bd., 509 S.W.2d 175 (Mo. 1979); Chimney Rock Nat'l Bank v. State Banking Bd., 376 S.W.2d 595 (Tex. Civ. App. 1964).

103. Bank of Commerce v. City Nat'l Bank, 484 F.2d 284 (5th Cir. 1973) (anticompetitive effect of new charter not purused on appeal); Industrial State Bank and Trust Co. v. Camp, 284 F. Supp. 900 (D. Mich, 1968), vacated as moot, 421 F.2d 1361 (6th Cir. 1969); Continental Bank v. 
At the federal level, defining "convenience and needs" has presented a recurring problem in bank merger litigation. In the leading case of United States v. Third National Bank of Nashville, however, the Supreme Court defined "convenience and needs" in a way that included competitive effects as an integral part of the standard. ${ }^{104}$ In Nashville, the Court considered whether a bank merger that provided a desirable banking service-improved management-necessarily advanced the "convenience and needs" of the community without regard to the other ways in which the community could have obtained the improved service. If the Court had considered only the gains on their face, the Nashville Bank would have had an easy "convenience and needs" defense, as would almost every bank combination. Such a result, however, would force courts in most inerger cases to weigh this unexamined public "benefit" against probable anti-conipetitive effects that often present a prima facie violation of ordinary antitrust standards. ${ }^{105}$ This result would dilute long-standing congressional policy on bank competition ${ }^{106}$ by introducing a highly ambiguous defense for almost all prima facie violations of antitrust merger standards. ${ }^{107}$ This cursory definition of "convenience and needs" would also risk social inefficiency by requiring society to pay for solne non-coinpetitive gain with lost competition or coinpetitive potential when such a cost may not have been a necessary price for the gain.

To avoid these obvious risks and to effectuate Congress' express procompetitive policies, the Nashville Court wisely limited the "convenience and needs" defense to cases where it appeared socially appropriate. $^{108}$ By direct imphication, this limitation included a competitive effects analysis in the definition of "convenience and needs": simply put, a transaction cannot nreet that standard unless it yields the gains to the public with the least loss of conipetition possible. ${ }^{109}$ In Nashville,

Nat'l City Bank, 245 F. Supp. 684 (N.D. Ohio 1965); Dauphin Deposit Trust Co. v. Myers, 401 Pa. 230, 164 A.2d 86 (1960) (market leader denied branch bank).

104. 390 U.S. 171, 190 (1967). See generally Note, Washington Mutual: A Judicial Amendment so the Bank Merger Act of 1966, 42 GEO. WASH. L. REv. 639 (1974) (convenience and needs authorizes agency evaluation of all the competitive effects of a combination).

105. 390 U.S. at 191-192; see also United States v. Phillipsburg Nat'l Bank \& Trust Co., 399 U.S. 350,372 (1970).

106. See supra text accompanying note 56.

107. This broad defense would require comparison of extremely disparate kinds of "gains" and "losses". See infra note 109; supra text accompanying note 52. The subjective nature of such comparisons also generally leads the Court to reject diffuse or wholly non-economically defined claims in merger cases. See United States v. Philadelphia Nat'l Bank, 374 U.S. 321, $370-371$ (1963); see also infra text acconpanying note 108.

108. 390 U.S. at 189.

109. This definition does not answer the issues raised by difficult hypothetical cases. Suppose, for example, that only a combination of all banks in the market can achieve certain socially 
the acquired bank had less restrictive ways to solve its management problems; therefore, the otherwise anti-competitive merger did not raise any "convemence and needs" imterest. ${ }^{10}$ One incidental, but important consequence for litigation of this approach is that courts need only to seek verification of claimed public benefits if the parties can also prima facie satisfy the least-restrictive-alternatives test as well.

Of the County National, Texas Mercantile, and Washington Mutual opinions only the last discussed Nashville. In domg so, however, the Ninth Circuit suggested that Nashville's least-restrictive-alternative analysis of "convenience and needs" applied only to Clayton Act challenges."11 This would mean that the "convenience and needs" phrase has one meaning in the first paragraphs of sections $1828(\mathrm{c})$ and

worthwhile advantages. Such combinations presumptively violate the antitrust laws. See, e.g. United States v. Philadelphia Nat'l Bank, 374 U.S. 321 (1963); United States v. Continental Can Co., 378 U.S. 441 (1964); United States v. Aluminum Co. of America, 377 U.S. 271 (1964). How can a court in such a case value the loss to competition and the gain to other public imterests? Some scale must be developed, and Congress has provided a basepoint by indicating that a monopoly may not be justified under the "convenience and needs" defense. See 12 U.S.C. \$ 1842(c) (1976). But see United States v. Aluminum Co. of America, 148 F.2d 416, 429-31 (2d Cir. 1945) (monopolist can avoid liability if monopoly is thrust upon it). With this basepoint in mind, a critical examination of the most likely form of non-competitive gains to society suggests that they will rarely, if ever, require major anti-competitive mergers for their achievement. Domination of specific markets is unnecessary to achieve large size, economies of scale, or large capital bases with which to cover risks. Benston, Hanweck, Humphrey, Scale Economies in Banking, $14 \mathrm{~J}$. MONEY, CREDIT, \& BANKING 435, 451 (1982). Moreover, risks requiring large capital bases can be handled efficiently through correspondent relationships. See Knight, Correspondent Banking, FED. Res. Bank of Kansas City Monthiy Rev. pt. 1-3 (Nov., Dec. 1970; Dec. 1971). See generally Carstensen, Regulating Banking in ahe Public Interest: The Case for an Open Approach to Chartering and Branching, 57 TEX. L. REv. 1085, 1089-101 (1979).

110. 390 U.S. at 189. The case was one of antitrust merger law because the government had shown a Clayton Act violation, see id at 192, but the interpretation of "convenience and needs" proceeded directly from the banking law.

111. Washington Mut. Sav. Bank v. FDIC, 482 F.2d 459, 463-64 (9th Cir. 1973). The court quoted Nashville regarding the antitrust question where the Supreme Court argued that the "convenience and needs" clause does not alter ordinary Clayton Act analysis: "Congress intended bank mergers first to be subject to the usual antitrust analysis . . . ." Id at 463-64. The Supreme Court next stated that if a merger fails the antitrust analysis then the "convenience and needs" defense may apply. 390 U.S. at 181-82. The passage does not define the standard for "convenience and needs"-a point made by the FDIC at the end of an argument for agency expertise and discretion. Washington Mutual Brief for Appellonts, supra note 43, at 16-17, 47-50. The FDIC's argument also implied that the Nashville position was one the agency might adopt ("the merger policy that the FDIC has adopted") and not one required by law, a distinction also designed to bolster "complete discretion" claims by the agency. The Federal Reserve Board's briefs in County Notional and Mercantile Texas make only passing reference to Nashville, County Nat'l Respondent's Brief, supra note 17, at 22,41, 48; Mercantile Texas Respondent's Brief, supra note 92, at 43, largely to distinguish the case. The Board's brief for reconsideration in County National also takes this tack, see Petition for Rehearing and Suggestion for Rehearing En Banc, County Nat'l Bancorp. v. FRB, 654 F.2d 1253 (8th Cir. I981) (en banc) at 1, 5, 7, 10, 12, 13, 14, and reveals why the agency's primary claim remains one of broad, almost unbounded, discretion "to deny applications." Id at 7 (emphasis in original). 
1842(2), 112 but a different meaning in the second paragraph of the same subsections and elsewhere in Title 12. The Supreme Court made no such distinction in Nashville, nor did the logic of its analysis suggest that such a distinction ought to exist.

Using the actual Nashville definition of "convenience and needs" leads to a relatively constrained model of agency discretion. Under this model, a bank regulator may not find that a proposal serves public convenience and needs if it also produces anti-competitive consequences and if its other ends are achieveable through less anti-competitive means. This finding would ordinarily lead to a denial of the proposal, ${ }^{113}$ and would provide a limit to agency discretion at least as rigorous as the Clayton Act standard adopted by the County National, Mercantile Texas and Washington Mutual courts. A Nashville-type standard, however, would produce different outcomes in specific cases. For example, it would affirm the FRB denial of County National's application and would overrule the earlier decision which had allowed a comparable transaction. ${ }^{114}$

Opponents of such a rigorous interpretation of the Nashville standard might argue that Congress never intended such dramatic restrictions on bank combinations. The bank merger statute arguably gives regulators varying levels of approval discretion: more when anti-competitive effects do not rise to the level of antitrust violations, less when they do. The phrase "take account of" in the statute's second paragraph is less commanding than "the agency shall not" in the first."15 Still, if an agency using the Nashville test finds that "convenience and needs" are not served, it must advance some other interest to justify the combination. ${ }^{116}$ For example, a bank regulator could find a general preference in the law for freedom of action, even for bankers, which would outweigh any small negative effects of transactions not serving public convenience and needs. ${ }^{117}$ Or an agency might adopt a long-

112. See supra text accompanying note 56 .

113. Unless other aspects of the transaction, such as a long range plan by the agency provided overriding reasons for approval against the general public interest. See infra text accompanying note 117.

114. Commerce Bankshares, Inc., 64 Fed. Res. Bull. 576 (1975).

115. See supra text accompanying note 56.

116. As the Nashville opinion makes clear, bank regulation should serve the public interest. 390 U.S. at 184. Therefore, it would be a clear abuse of discretion to allow combinations that not only fail to serve the public interest in the least restrictive manner but that also, in fact, disserve that interest because of anti-competitive effects.

117. See Carstensen, supra note 109, at 1104-05; see also J. Hurst, LAw AND the Conditions of FreEdoM in the Nineteenth-Century UNITED States (1956) (Professor Hurst argues that the desire to free human will from unnecessary legal bounds is a strong, unifying theme of Amerimegal history). 
term view of competition and "convenience and needs," and ignore short run potential anti-competitive effects. 18

This relatively burdensome view of the "convenience and needs" defense provided by Congress fits the real-world observation that specific assertions of the defense are rarely supportable. In lobbying for the legislation, bankers and bank regulators seemed to have either misstated or not fully analyzed facts. ${ }^{119}$ Congress, however, assumed these facts were true and allowed an exception for any case fitting them-the "convenience and needs" defense. That cases rarely fit these fact patterns does not disappoint congressional expectations; it merely illustrates that the testimony given to Congress did not reflect reality.

For these reasons, a Nashville-type standard does not offend either the letter or the spirit of the bank merger law. Nor does the approach bar all combinations, even in its most rigorous formulations. Obviously, all per se pro-competitive combinations, such as those strengthening small competitors by raising them to a more efficient size or those expanding geographic coverage when other entry appears legally or economically infeasible, would merit approval. Other cases would simply require an imquiry into anti-competitive effects, with the agency bearing the burden of proof. For example, the FDIC in Washington Mutual provided a colmection between its theory of competitive effects and the facts of the case too tenuous to justify the finding of anti-competitive effect if the burden were on the agency. Generally, the acquisi-

118. For example, a regulator might allow a merger that would expand the number of retail offices and reduce actual competition in that market, by projecting that the expansion will eventually trigger competition or make the new eutity a competitor in other markets where it would not have been otherwise.

119. For example, the President of the American Bankers Association stated that banking agency decisions im Philadelphia and New York were wholly justified. To amend Bank Merger Act of 1960: Hearings on S. 1698 Before the Subcomm. on Domestic Finance of the House Comm. on Banking and Currency, 89th Cong., Ist Sess. $49-50$ (1965) (testimony of Reno Odlin); see also, id. at 280 (statement of Baldwin Mauell). A Chicago banker justified an anti-competitive merger by pointing out that it fulfilled the need for new managers. Id. at 211-12 (testimony of Donald Graham). A California bank regulator suggested that the banking agencies were fully able to consider competition in their overall analysis. To Amend Bank Merger Act of 1960: Hearings on S. 1698 Before the Subcomm. of the Senate.Comm. on Banking and Currency, 89th Cong, 1st Sess., 128-32 (1965) (testimony of John O'Kane); see also id at 74-75 (testimony of G. Russell Clark).

In fact, the justification for big bank mergers vanishes upon examination of most cases. See, eg., United States v. Provident Nat'l Bank, 280 F. Supp. 1 (E.D. Pa. 1968) (merger of two Philadelphia banks, both smaller than Philadelphia National Bank, held illegal and without convenience and need justification). Moreover, bank agencies often "find" benefits that they later cannot prove. Since the 1966 amendment, no banix merger found by a court to be unlawfully anticompetitive has been upheld on "convenience and needs" grounds. Cf. H. R. Rep. No. 1221, 89th Cong., 2d Sess. 2-3, reprinted in 1966 U.S. CoDE CONG. \& AD. NEws 1860, 1861-62 (This report contends that, absent special defenses, banking agencies would "find it difficult to deal with the foundering bank."). Thus, the "convemence and needs" defense has had very limited utility. 
tion of small, non-competing banks by very large banks would not seein to provide sufficiently measurable effects to raise competitive concerns. By default, this leaves another safe harbor for combinations.

\section{B. The Restraint of Trade Route.}

Defining "convenience and needs" provides a clear path to balanced and properly limited agency discretion. Defining the prohibition on approval of any application that "would constitute a restraint of trade" gives a less clear route. The best point of departure is the Manufacturers Hanover decision, which held a merger of large banks unlawful as a restraint of trade because it eliminated actual coinpetition between substantial entities. ${ }^{120}$ Although the parties did not appeal and the case has not been followed, ${ }^{121}$ the bank merger statutes manifestly codify this approach for bank regulatory decisions. ${ }^{122}$ Like the Nashville version of the "convenience and needs" analysis, this "restraint of trade" approach first calls for the regulatory agency to identify any possible restraints that may result from the combination. Next, the agency examines the character of the market: are the firms substantial? Fimally, the agency may have to decide whether the restraimt has some competitive significance. Certainly, positive findings in all of these steps identifies a restraint that requires prima facie disapproval of the transaction unless its gain to convenience and needs outweighs its trade-restraming effect. This defines "convenience and needs" as only a defense to prima facie disapproval; such a status does not circumvent the law the Nashville court has mandated because it must still be read according to the Nashville definition.

120. 240 F. Supp. 867, 893 (S.D.N.Y. 1965).

121. Despite over 400 citations from the time of the Manufacturers Hanover opinion to the date of this comment, no court in an antitrust suit has relied on the restraint theory to find a merger unlawful.

122. See 12 U.S.C. $\$ \$ 1828,1842$ (1976). On the theory that Congress does not enact mere surplusage, courts should distinguish between the general antitrust standards, 15 U.S.C. \& 10 (1970), which apply to mergers in all industries, and the bank merger standards specifically developed to govern agency review of specific combinations. In order to equate the two standards, courts must ignore the restraint of trade standard found in sections 1828 and 1842 and pretend that the Clayton Aet standard alone governs agency decisions. Only by so doing can they equate sections 1828 and 1842 with the general Clayton Act standard applied by the Justice Department under 15 U.S.C. \& 10 (1976)-an analytical step which essentially reduces sections 1828 and 1842 to the status of surplusage and makes "convenience and needs" only a defense rather than a factor required to be considered in "every case." Cf. United States v. First City Nat'1 Bank, 386 U.S. 361, 362-64 (1967). The Government's failure to base its action on the Bank Merger Act of 1966 does not render its complaint defective, because "an action challenging a bank merger on the ground of its anticompetitive effects is brought under the antitrust laws." Id. at 363. The Bank imerger Act provides a defense of "convenience and needs" to the merger's proponents. 
This formulation of the restraint of trade analysis still differs from the pure "convenience and needs" rule in two ways. First, the facts of Manufacturers Hanover support a narrow definition of "restraint of trade" that might reach only cases in which the parties are actual competitors. Only the merger of actual competitors causes an instantaneous loss of competition. Any merger, however, eliminates the acquired firm's freedom of action and so produces a more broadly stated "restraint" on competitive freedoin. ${ }^{123}$ A reasonable gloss on this expansive reading would be to require an agency to show that the "restraint" has some reasonable potential to affect competition. ${ }^{124}$

The second difference between the Bank Merger Act's restraint of trade analysis and the "convenience and needs" test derives from Manufacturers Hanover's emphasis on the absolute size of the entities imvolved. Each bank in that combination had at least $\$ 1$ billion in resources and ranked among the iargest banks in the nation. ${ }^{125}$ A rule could follow from this observation: whenever a combination involves banks so large that each can easily approach the upper limits of economies of scale without a inerger, it involves impermissible restraint. This rule ignores combinations involving at least one party below the scale threshold and thus helps to avoid interference in sinaller combinations unlikely to have measurable anti-competitive effects (just as the "convenience and needs" test did) with perhaps a slight bias towards the banks. ${ }^{126}$

\section{The Routes Compared and Applied.}

Under either Nashville's "convenience and needs" analysis or Manufacturers Hanover's "restraint of trade" route the County National case should be reversed. Under a "convenience and needs" analysis, the County National combination would provide no unique benefits

123. The classic common law of restraint of trade, for example, has dealt repeatedly with restraints, whether in geographic or product dimensions, limiting future potential competition. See, eg., Karpinski v. Ingrasci, 28 N.Y.2d 45, 768 N.E.2d 751, 320 N.Y.S.2d 1 (1971).

124. For example, a restraint on an individual's freedoin of action would arguably raise no coinpetitive concern because it does not have a significant potential to affect market competition, see Lektro Vend Corp. v. Vendo Co., 660 F.2d 255 (7th Cir. 1981), cert. denied, 455 U.S. 921 (1982); but see Klor's v. Broadway Hale, 359 U.S. 207 (1959), the actual potential for discernable coinpetitive effect does not necessarily follow from proof of restraint in the abstract. A presumption of such effect may, however, inake sense if the restraint of trade test also includes a test of significance or degree of effect.

125. 240 F. Supp. at $893-94$.

126. If the scale threshold were set, not by the size at which economies of scale become unlikely or freely obtainable by internal growth at lower cost, but instead by the higher threshold of "substantiality" prescribed by the new director interlock laws, see supra note 83 , the threshold would be even more favorable to the banks. 
and would create a loss of actual competition, thus producing a negative effect on the convenience and needs of the community. This negative effect would bar the merger absent soine other public interest claim such as long range planning. The arguments in the case, however, hardly support any such claim. The County National combination also eliminated actual competition between two banks of such substantial absolute size that further scale economies appeared unlikely and the change in size produced by the merger could not, in any event, yield such economies. ${ }^{127}$ Consequently, the restraint of trade standard would bar the inerger unless the threshold for substantiality were raised. 128

In Mercantile Texas, the "convenience and needs" approach would again yield objections to the merger. A loss of potential competition would occur without any offsetting gains not otherwise achievable. Under a broad "restraint" standard, objection to the merger seeins even more likely than in County National because Mercantile had deposits in excess of $\$ 2$ billion and Pan National had deposits of over $\$ 500$ million. If, however, the restraint standard requires a combination of actual competitors, the inerger would easily survive.

As discussed earlier, the Washington Mutual transaction arguably presents no anti-conipetitive effect. ${ }^{129}$ For that reason, even the absence of public gain would not necessarily bar the inerger as contrary to the convenience and needs of the community because other policiesfor instance, frcedom of action-would require approval. This simply illustrates that under the "convenience and needs" standard, agencies must approve neutral cases. On the other hand, a very broad restraint of trade test could make the saine merger seen objectionable because that test focuses on the loss of the small savings and loan association's independent competition. A requireinent that the restraint also involve discernable risks to competition would, however, preserve the combination's neutrality and give a result again paralleling that of the "converience and needs" approach.

Of the two paths, the convenience and needs route provides not merely a defense for inergers and acquisitions but a positive standard

127. The banks disputed this conclusion by the FRB. See supra note 24. But see supra note 38 (Mercantile Texas banks). Recent analysis has questioned the need for mergers to achieve scale advantages. Benton, Hanweck, Humphrey, Scale Economies in Banking 14 J. MONEY, CREDIT \& BANKING 435, 451 (1982) (Most bank mergers are likely to imcrease operating costs); see also, Carstensen, supra note 109 , at 1098-101.

128. Note that if the director interlock standards set the "substantiality" threshold, see supra note 126, the County National ban's would not qualify as substantial and thus no "restraint" would be presumed.

129. See supra text accompanying notes $41-45$. 
applicable to most bank regulation contexts. The restraint route, however, appears generally applicable only to larger combimations.

Because both approaches provide useful insights into the proper scope of agency discretion and the proper outcomes in bank combinations, and because so many different kinds of bank transactions are possible, accomodating both seems desirable. This is not impossible; the two approaclies can yield consistent outcomes in certain formulations. For exainple, the restraint standard could be applied only to those cases in the Manufacturers Hanover mold: combinations of extremely large banks (combined deposits of more than $\$ 1.5$ billion, for example) regardless of market share. This would comport with the recent ban on director interlocks in analogous, non-merger situations ${ }^{130}$ and would help articulate the implied statutory support for disfavoring most large bank combinations absent special factors. ${ }^{131}$ Fully satisfying the Nashville convenience and needs test could demonstrate such special factors; otherwise, regardless of market share, large bank combinations would be forbidden. ${ }^{132}$

The convenience and needs standard would also govern most remaining conibinations, those not involving substantial participants as both acquirer and acquiree. Some of these combinations could involve sufficient anti-competitive potential to violate the Clayton Act standard, but most would not. In the latter cases, the controlling competitive assessment would oceur during application of the second paragraphs of the bank merger and bank holding company statutes, which state that the agency nuust "take account of" the convenience and needs of the community. This would not only provide the proper time for the banks to argue that convenience and needs considerations support their proposals, it would also provide a proper amount of regulatory discretion to approve or disapprove the transaction with inore than the parties themselves in view, because it would allow the regulators to consider, for example, long run planning of market structure.

130. See supra note 83.

131. See Holland, \$500 Million Limitation on BHC Acquisitions?, 97 BANxing L.J. 884 (1980) (in the late 1970's the FRB seemed to have a policy of denying mergers where the acquiring firm exceeded $\$ 1$ billion and the acquired firm exceeded $\$ 500$ million).

132. Arguably, the restraint of trade standard should not apply when merging banks are not direct competitors and the combination does not have a discernable effect on potential competition because such an apparently total bar would preclude arguably innocuous combinations of large, noncompeting banks with relatively minor market shares. Such combinations, despite an inherent restraint on separate development, might serve a long run interest in creating and maintaining a competitively structured banking market. The restraint of trade standard, lowever, can easily accommodate this long run interest as an overriding public interest factor fully justifiable under the Nashille test. 


\section{The Circuit Courts' Results-Half Correct}

The two suggested approaches to resolving the competing claims in County National, Mercantile Texas, and Washington Mutual would reject the legal rule proposed by those cases, and would certainly reverse the first two. What, then, can be said of these opinions? They advance two propositions. First, they reject banking regulators' claims for an all-but-unlimited scope of discretion. Second, they inandate approval of bank coinbinations lacking any social justification in order to achieve a consistent rule governing those regulators' actual discretion.

In advancing the first proposition, the courts reach a long-overdue result. The Coinptroller and Federal Reserve Board simply caumot justify the kind of ad hoc, inconsistent decision inaking that has characterized their rulings. ${ }^{133}$ The bases for banking decisions, especially in the area of ownership, are not so arcane as to foreclose "inexpert" judicial review, nor so divergent as to preclude inuposition of a consistent, predictable pattern.

In advancing the second proposition, (choosing a standard limiting the discretion of federal banking agencies), the three circuits have, however, erred. No inore justification exists for allowing socially ineffcient combinations than for allowing unbridled agency discretion. ${ }^{134}$ Even if their negative effects are shight and do not violate the antitrust laws, inefficient combinations do not serve "the convenience and needs of the community." When principled judicial review must ignore such effects to achieve consistency, then an overriding justification for the inefficiency might arise. The Eighth, Fifth, and Ninth Circuits assumed that such a justification existed. The narrow arguments that the contending parties presented the courts undoubtedly contributed to this conclusion. Nevertheless, the results, though nore understandable in this context, are still incorrect.

Consistency did not require approval of anti-competitive, undesirable combimations. The two routes proposed earker, both grounded in statute and case law, would have rationally limited agency discretion

133. For the Federal Reserve Board, compare Commerce Bankshares, 64 Fed. Res. Bull. 576, (1978), affd mem sub nom. Manchester-Tower Grove Community Organization/Acorn v. Board of Governors of Fed. Reserve Sys., 607 F.2d 494 (D.C. Cir. 1979) wilh County Nat'l Bancorp. v. FRB, 65 Fed. Res. Bull. 763 (1979), vacated en banc, 654 F.2d 1253 (8th Cir. 1981). For the Comptroller, compare National Bank v. Saxon, 268 F. Supp. 720 (W.D. Pa. 1967) (anti-competitive effect of branch not relevant to decision) with Citizens National Bank v. Wachovia Bank \& Trust Co., 329 F. Supp. 585 (M.D.N.C. 1971) (pro-competitive effect of branch justified grant).

134. In fact, the two evils produce many of the same losses in competition and public benefit, and thus should require a similar overriding public interest in rejecting their continued unnecessary existence. See infra text accompanying note 136 for an observation that no overriding interesi appears. 
while supporting the agency decisions under review in two and providing a basis for reversing the third. Either route would have provided the courts a consistent standard for the review of all comparable decisions. Either alternative could have greatly encouraged both public and private interest actors to seek and receive principled judicial review of questionable bank combination decisions. Together, the two routes could provide a comprehensive, consistent inethod; ${ }^{135}$ and, either together or separately, they would not require social inefficiency.

In its search for consistency, a court should not foolishly embrace a rule that serves some goals poorly and others well when an alternative would serve all goals as well or better. The Eighth, Fifth, and Ninth Circuits, in seeking to limit the essentially procedural regulatory discretion of the FRB and FDIC, ignored the substantive public interest in bank competition. The Supreme Court, Congress, and most state courts, however, regard that public interest in competition as a core concern in banking regulation. The County National, Mercantile Texas and Washington Mutual rule mandating merger approvals needlessly sacrifices that public interest. ${ }^{136}$

\section{The Future of Bank Competition-The Proper REGULATORY ENVIRONMENT :}

Banking has begun a series of radical changes that will continue at least imto the next decade. The mdustry has, in the process, started to shed the encrusted regulatory process controlling both its ownership structure and the scope of its business activities. As this process accelerates, banks may expand into multistate or nationwide organizations offering a. far greater range of financial services; ${ }^{137}$ savings and loan associations and credit unions may become much more like banks in the scope of their busimess; ${ }^{138}$ and non-bank financial institutions may assunie increasingly important roles in many activities. ${ }^{139}$

135. But see Reid, Legislation, Regulation, Antitrust and Bank Mergers, 92 BANkING L.J. 6, 28 (1975) (calling for congressional action).

136. This conclusion rejects the position of Metzger and Greenfield, supra note 5, at 846, that in order to constrain discretion it is essential that banking agencies employ only the Clayton Act standard when denying a combination.

137. See, eg., Geographic Restrictions on Commercial Banking in the UNited States: The Report of the President (1981); Ginsberg, Interstate Banking, 9 Höfstra L. REV. 1133, 1175-218 (1981).

138. See, e.g., Consumer Checking Equity Act of 1980, Pub. L. No. 96-221, 94 Stat. 132 (1980) (amending 12 U.S.C. $\$ \$ 1382($ a), 1757 authorizing Savings and Loan Associations and credit unions to offer checking accounts).

139. Major brokerage houses and mutual funds now offer accounts that allow securities investinent savings with interest and checking privileges. $C f$. Raven, supro note 12, at 389. 
Banking, however, has been externally regulated for a long time and is not as loosely structured or organized as it might have been in a laissez faire market. 140 Starting from this artificial structure, rapid change inay yield an unnecessarily anti-coinpetitive structure without even violating the antitrust laws. ${ }^{141}$ Because of such risks, a regulatory context emphasizing not only the prevention of gross anti-coinpetitive effects, but also the positive encouragement of competition, would probably appeal to the thoughtful observer. A fiexible "convenience and needs" test would, at least in part, fulfill this desire by allowing assessment of present and future competitive potential, and by permitting denial of transactions that appear to be anti-competitive without offering otherwise unachievable benefits. ${ }^{142}$

A second general social concern also encourages rules against unjustified combinations. Rapid banking evolution unay yield inore than a thousand large national financial institutions, or less than a hundred even larger ones. After reaching some minimuin (but substantial) size, additional growth produces hittle or no increase to economies of scale but also no inefficiencies. ${ }^{143}$ Assuming a moveinent to a national market in which efficiency depends upon greater aggregate sizes, the dccision whether to have one hundred or one thousand firms cannot rest on traditional antitrust analysis. With one hundred actual or potential competitors, traditional econoumic theory provides little support for conclusions of oligopolisic conduct. No antitrust violations will oceur; no significant competitive risks will probably exist.

Still, in the broader social view, the decision whether to have one hundred or one thousand decisionmakers controlling access to credit seeins important. Even without traditional economic unarket power, a decisionmaker still has discretion to act or not to act. ${ }^{144}$ In finance, many other economic actors will find these choices of vital interest.

140. Cf. United States v. Marine Bancorp., 418 U.S. 602, 627 (1974) ("“A]pplication of the doctrine [of potential competition] to commercial banking must take into account the unique fedexal and state regulatory restraints on entry into that line of commerce.").

141. Cf. Halbrook \& Savage, Interstate Commercial Banking: The Antitrust Issues, 98 BanknNo L.J. 747, 763 (1981) ("[O]nly a court ruling that section 7 requires de novo or foothold entry when a merger leaves competitive conditions in the marketplace unchanged would enable the existing antitrust laws to be effective in forestalling rising aggregate concentration . ... .").

142. The standard posited in this comment, the "convenience and needs" test, would not bar truly neutral transactions.

143. See E. Penrose, The Theory of the Growth of the Firm (1959).

144. Dewey, The New Leaming: One Man's View, in Industrual Concentration: The New LeARning 1, 13 (H. Goldschmid, H. Mann, \& J. Weston ed. 1974); see also C. LindBloM, Politics and Markets (1980); Blake, Conglomerate Mergers and the Antitrust Law, 73 Col. L. Rev. 555, 570 (1973); Carstensen and Questal, The Use of Section 5 of the Federal Trade Commission Act 10 Attack Large Conglomerate Mergers, 63 CoRneul L. Rev. 841, 864-65 (1978). 
The fewer discretionary decisionmaker's controlling credit access, the greater the effects on others of their discretion, and the higher the risks that their power will become a major social problem if the number of credit sources diminishes. Moreover, any decrease in the diversity of credit grantors, even if it provides some marginal efficiency gain, could easily trigger harsher direct control over credit discretion. ${ }^{145}$ Indirect control, by maximizing the number of actors with discretion, would probably cost less than direct regulation. Either the "convenience and needs" or "restraint of trade" standard would encourage regulators to engage in such maximization and avoid the social costs of direct regulation.

Denying federal banking authorities the chance to consider these broader economic and social implications of combinations that produce no unique benefits means mandating needless social and economic costs. To ensure effective bank regulation in the future, bank agencies must receive guidance exactly opposite from that given in the County National, Mercantile Texas, and Washington Mutual decisions.

In their search for a consistent standard of constraint on banking agency discretion, the Eighth, Fifth, and Ninth Circuits have understandably, but foolishly, adopted one that requires approval of socially and economically undesirable combinations. Their consistency was unnecessary. They had alternatives available that could have both constramed agency discretion and protected the nation from unnecessary present-and future-social and economic costs.

145. The risks are already clear in legislation regulating access to personal credit and to neighborhood reinvestment. Such legislation, a rational response to abuse of discretion by market actors, still imposes significant administrative costs and creates real risks to the dynamic of the econouny. See B. KIEIN, DrNamlc Economics 217, 221, 231 (1977). 